in aggressive, violent, and suicidal behaviour. We would like to point out a preliminary study which investigated the effects of cholesterol-reducing agents on the serotonin-related behaviour in vivo (Dursun, 1992).

Rather high doses of cholesterol-lowering agents, gemfibrozil and cholestyramine, both significantly blocked the inhibitory action of a serotonin-1A receptor agonist ligand on the serotonin-2 receptormediated-behavioural response (head-shakes), while gemfibrozil significantly potentiated this behavioural response and cholestyramine showed a trend towards potentiation of the same behaviour in rodents (significantly low plasma cholesterol levels compared with control animals have been confirmed by biochemical studies after behavioural studies) (Dursun, 1992). These preliminary results show that cholesterollowering agents can indeed alter both serotonin-2 receptor-mediated behaviour and a serotonin-1A/ serotonin-2 receptor interaction in vivo. Therefore, alterations of the functional state of the serotonin receptor subtypes and their interactions by the cholesterol-lowering agents may be implicated in understanding the involvement of serotonin in the relationship between low serum cholesterol and suicidal behaviour. However, further preclinical and clinical research is needed to understand the mechanisms of this relationship. Dursun, S. M. (1992) An Investigation into the Pharmacology of Tics
and Tic-like Movements, PhD Thesis. Birmingham: Aston
University.

SERDAR M. DURSUN

University of Leicester

Michael A. ReVeley

Leicester LE2 $7 \mathrm{LX}$

\section{Concepts of illness and disease}

SIR: Is there any stronger a prima facie case for linking the abuse of psychiatry for political reasons in the former USSR with difficulties about the concept of mental illness than there is for, say, linking the abuse of surgery for financial reasons in capitalist countries with difficulties with the concept of physical illness? A simpler, and perhaps less self-deprecatory, view is that the particular susceptibility of psychiatry to totalitarian abuse is merely a consequence of the practical, rather than conceptual, opportunity provided by the need to treat psychiatric patients on occasion without their voluntary consent.

In their article (Journal, June 1993, 162, 801-810), Fulford et al build on the notion (Fulford, 1989) that there is a distinction to be made between biologicalscientific and social-evaluative concepts with a claim that "disease really is an evaluative concept". We are therefore asked to allow priority to the latter paradigm of a binary 'is-ought' dichotomy between process and praxis.

An alternative model, tripartite rather than binary, could be based on Popper's three 'worlds' (e.g. Popper \& Eccles, 1977). Popper's 'world 1', or physical world, was distinguished from the world of subjective experiences (world 2), and from what he called "the products of the human mind" (world 3 ).

Adapting this model, medicine can be conceived as being continuously involved in three interactive realms. The first, or objective realm, is concerned with disease as dysfunction, with medicine functioning as an essentially scientific enterprise. In the second, or subjective realm, illness is perceived as distress, with medicine responding as an empathic art. In the third, or social realm, sickness becomes an enacted role, with medicine engaged as a social or political activity. For medicine to be practised appropriately, it is necessary to identify honestly which realm, or realms, are being inhabited at which times, and to be able to move accurately and flexibly between them.

It seems uncontentious that there will be political implications if social evaluative judgements (realm 3 ) are rationalised as scientific ones (realm 1), and that this applies equally to physical illness. No doubt this is often done with benevolent intent, as, for instance, when invalidity status is granted to unemployed miners with relatively mild chronic obstructive airways disease. However, if psychological medicine has a special vulnerability, apart from legal questions of consent and competence, this could be found in the particularly disgusting and disturbing nature of its subjective realm (realm 2). Thus, psychiatrists may be especially liable to use scientific concepts defensively, not in order to deny that ethical judgements are being made in the interests of social expediency, but principally to protect themselves from states of aesthetic 'disease'.

FULford, K. W. M. (1989) Moral Theory and Medical Practice. Cambridge: Cambridge University Press.

POPPER, K. R \& ECCLES, J. C. (1977) The Self and Its Brain. London: Routledge and Kegan Paul.

Tim HeLME

\section{St Thomas' Hospital \\ Lambeth Palace Road \\ London SEI 7EH}

\section{Neurological complications of anorexia nervosa}

SIR: The recent review of the medical complications of anorexia nervosa by Sharp \& Freeman (Journal, April 1993, 162, 452-462) made compelling reading. One factor that did not receive attention, however, 
was the potential for neurological impairment in anorexia nervosa. While computerised tomographic changes have been documented in association with anorexia (Krieg et al, 1988), little has been written about definite neurological syndromes in relation to this condition. We have recently reported a case in which an episode of starvation in a male anorexic produced an acute neurological deficit (a neurogenic stutter) which thankfully disappeared upon refeeding (Byrne et al, 1993). As starvation/malnutrition is a well recognised cause of mental deterioration, with the associated lethargy, apathy and depression well described, we feel that neurological complications of anorexia are worthy of mention, and indeed worthy of further evaluation.

Byrne, A., Byrne, M. \& Zibin, T. (1993) Transient neurogenic stuttering in a male anorexic. International Journal of Eating Disorders (in press).
Krejg, J. C., Pirke, K. M. \& Lauer, C. (1988) Endocrine, metabolic and cranial computed tomographic findings in anorexia nervosa. Biological Psychiatry, 23, 377-387.

\section{Alan Byrne \\ MARY BYRNE \\ GARY HNATKo \\ TERRY ZIBIN}

University of Alberta

Edmonton, Canada

\section{CORRIGENDA}

Journal, July 1993, 163, 129. The letter "Bloodletting in bulimia nervosa" was also written by Tom Henderson; Bellsdyke Hospital, Bellsdyke Road, Lambert.

Journal, August 1993, 163, 226. In Table 3, the $P$ value for the comparison of mean scores for 'Private leisure' should be $<0.01$.

\section{A HUNDRED YEARS AGO}

\section{The need of medical evidence in cases of alleged insanity}

Our attention was recently directed to a curious anomaly in certain legal proceedings at the Cape, an account of which we published in a letter from Dr. Cartwright Reed in our issue of Jan, 21st, at page 167. The writer had up to the occurrence of the case which he records been uder the impression that "no person could be pronounced of 'unsound mind' without the support of medical testimony." He doubts whether any British jury would venture to return such a verdict unless it was supported by expert evidence. It cannot but be regarded as a most unsatisfactory proceeding that any person should be adjudged to be insane without the support of medical testimony. That a British jury has power, even in a criminal case, to return a verdict of "Guilty of the act, but insane at the time it was committed," without medical evidence is shown in the case of the Rev. Henry J. Dodwell, who was tried before the late Baron Huddleston in March, 1878, for "assault" after firing a pistol at the then Master of the Rolls, Sir George Jessel. Mr. Dodwell was ordered to be detained during Her Majesty's pleasure as a criminal lunatic. We are strongly of opinion that cases where the existence of insanity is alleged ought never to be decided without medical evidence.

\section{Reference}

Lancel, 18 February 1893, 375. 